\title{
Religious practices and national development
}

\author{
Johnson Olusegun Ajayi ${ }^{1}$, Bodunde David Oluwafemi \\ ${ }^{1}$ Department of Sociology, Faculty of the Social Sciences, Ekiti State University, PMB 5363, Ado-Ekiti, Nigeria \\ ${ }^{2}$ Department of Intelligence and Security Studies, College of Social and Management Sciences, Afe Babalola University, PMB 5454, \\ Ado-Ekiti, Nigeria
}

Email address:

delight_top@yahoo.com (J. O. Ajayi),bodavisng@yahoo.com (B. D. Oluwafemi)

\section{To cite this article:}

Johnson Olusegun Ajayi, Bodunde David Oluwafemi. Religious Practices and National Development. Social Sciences. Vol. 3, No. 4, 2014, pp. 105-111. doi: 10.11648/j.ss.20140304.11

\begin{abstract}
Nigeria is a multi-religious society. These religions can be grouped under three principal and dominant types which are Christianity, Islam and Traditional African Religion. Religion is held with utmost passion, devotion, reference and sacredness in Nigeria, so much so that it has become a veritable tool in the hands of both political and non political leaders for the psychic and emotional manipulations of adherents. No wonder Marx sees religion as mere illusion, a way of rationalizing man's frustrations, an opium that sedates and placates the pains of exploitation and oppression by the nuveaux riché, whereas Durkheim saw it as a social institution that serves to give meaning to man's existential predicaments. Nigeria today is one of the most religious societies in the world, but these various beliefs and teachings have not changed to any appreciable extent the lives of the adherents and the nation as a whole. What is witnessed instead is one form of religious crisis or another leading to; maiming, looting, massacre and horrendous bloodshed of innocent and unprotected citizens. Every religion in Nigeria plays the blame game, to an extent that the practice of the same teachings of love, peace, unity and brotherhood each religion claims to instruct becomes a dirge and mirage. This study is therefore set to investigate religious practices in Nigeria and the effect on the development of the society using exploratory method. Though religion could be a source of social unity and cohesion in a social setting, it was discovered that over the years in Nigeria, religion has merely led to persecution, torture, wanton bloodbath and destruction of social and economic materials.
\end{abstract}

Keywords: Religion, Christianity, Islam, Morality, Sacredness, Religious Crisis

\section{Introduction}

Religious beliefs and practices though diverse, exist in all known human society ranging from the very simple to the most complex. While some religions worship a single supreme being, others are polytheistic. Religious rituals and prescriptions are no less varied than religious beliefs. A ritual may be a ceremony of adoration, adulatio and supplication addressed to an all-wise, all-knowing, ever present and merciful one. It may be a way of propitiating a being that would otherwise bring evil upon the community; it may be a solemn and quiet assembly or it may include dancing, sexual rites, and the release of feeling [Broom and Selznick, 1973:393]. Religious emotions run the very gamut of reverence to terror, joy to self-abasement, ecstasy and peace of mind.

All efforts to account for the universality of religion by the early sociologists tended to see it as a socially transmitted relic of man's pre-scientific and primitive past, but modern social science takes a different approach tracing the universality of religion not to man's propensity to make false interference, but to traits of human condition that persist even in an age of science. The explanation of human religiosity is sought in the basic functions it performs for individuals and the society. The foundations of religion can also be traced to individual psychic needs and the requirements of social solidarity, the need to overcome fear and anxiety, making the world comprehensible, the search for self transcendence, celebration of human powers and achievements and the quest for ultimate meaning.

However, the defining characteristic of religion is the creation of the sacred, imbued with special meaning or worth, and often treated with reverence, awe, and respect. Anything can be made sacred, but when it becomes sacred it is perceived as different from the everyday world. What is sacred is not a mere means or instrument, though it may 
be used in worship or in a ceremony, it is itself an object of awe and reverence set apart for respect and adulation. The creation of sacredness lays a solid pedestal for faith and moral obligation since what is sacred has its own claim to respect and obedience. To recognize, create, elaborate, and protect the sacred is the distinctive competence of religion [Bellah, 1970: 168].

\section{Conceptualizing Religion and Development}

The concept of religion is like any other sociological concept. It is easy to use in ordinary discourse, but difficult to define precisely hence it has been variously defined and looked at from various angles by authors, theoreticians and sociologists, many of which do not appear to be religious by themselves. For example, religion involves gathering together in groups. It involves communal eating and drinking. It involves theoretical discourse about the nature of the universe, and the position of man in it. In spite of all these multi-faceted features of religion, an average person can tell when others are engaged in religious behavior or not. Durkheim [1947] defines religion as a unified system of beliefs and practices relative to sacred things, uniting into a single moral community all those who adhere to those beliefs and practices. Durkheim felt that religion was created by the society and at the same time the foundation of society while Johnston and Sampson [1994] sees religion as a system of social coherence commonly understood as a group of beliefs or attitudes concerning an object, person, unseen or imaginary being, or system of thought considered to be supernatural, sacred, divine or highest truth, and the moral codes, practices, values, institutions, and rituals associated with such belief or system of thought. It is a framework within which specific theological doctrines and practices are advocated and pursued; usually among a community of like-minded believers [Johnston and Sampson, 1994].

Religion [religio] has two typical etymological sources [Derrida, 1998]. In the first place the Latin word relegere, comes from the root word legere, that means to bring together, to gather or to harvest. While in the second instance, religare, which comes from the word ligare, means to bind or to tie together [Benveniste, 1973]. The first meaning recognizes the religious foundations of any social group that is gathered together. The second indicates the disciplines or morality that is necessary for controlling and regulating human beings. Kirkpatrick [2005] sees religion as psychological attachment, a powerful emotional relationship to things. Tylor [1958 [187], defines religion as a belief in spirits. Spirits were gods, animating powers, animal-spirit companions, etc, all of which seemed to have a religious cast.

On the other hand, Development could be defined as a process of economic and social transformation that is based on complex cultural and environmental interactions.
According to Walter Rodney, development is the process that includes: Physical development which includes manmade goods produced by use of technology, Cultural development which comprises of the values, norms and traditions of a society, and Personal development which includes the psychological directions of individuals [Akwalla, 2009].

According to Seers [1979] the purpose of development in the society is to reduce poverty, inequality, and unemployment. For Sen [1999], development involves reducing deprivation or broadening choice. Deprivation represents a multidimensional view of poverty that includes hunger, illiteracy, illness and poor health, powerlessness, voicelessness, insecurity, humiliation, and a lack of access to basic infrastructure.

Arising from the fore goings, development in a nation is the capability of a country or countries to improve the economic and social wellbeing of the people e.g. by providing security and social amenities which includes quality education, portable water, transportation infrastructure, medical care, employment etc [Okechukwu, 2012]

\section{Theoretical Frame of Reference}

\subsection{The Protestant Ethic and the Spirit of Capitalism}

In his book, Protestant Ethic and the Spirit of Capitalism Max Weber, [1958] a German economist and sociologist argued that protestant doctrine shaped the personalities of the rising class of entrepreneurs in which capitalism had its origin. He stressed that protestant ethic was ascetic encouraging rejection of worldly affairs, an austere lifestyle and rigorous self discipline, this in order words produced people who worked hard in their careers or callings with single mind. Making money was a concrete evidence of success in one's calling.

Weber was of the view that money seekers are traditionally engaged in speculative projects gambling in order to gain rewards. Their successes lead them to spend money frivolously on consumption and seek for leisure without a need for harder push to make more money. He stressed that ascetic protestant had a different attitude to wealth characteristic of capitalistic essence of pursuit of profit and forever renewed profit. Weber in his argument was of the opinion that the spirit of capitalism is not simply a way of making money, but a culture with ethics, duties and obligations. Making money became both a religion and business ethics. The protestant interpretation of profit making justified the activities of the businessman. Weber also explained further that two of the basic principles of capitalism which are standardization of production and the specialized division of labor were both encouraged by Protestantism stress on uniformity of life and emphasis on fixed calling [Haralambos et al, 2004].

In other words Protestant religion compels individuals to religiously follow a secular vocation with as much zeal as 
possible for profit which is not to be frivolously spent but judiciously utilized or ploughed back to business for more accumulation of wealth in line with capitalistic behavior that put primary emphasis on formal rationality of accounting in the pursuit of profit maximization. Weber noted the importance of the creation of wealth and the restrictions on spending it, which encouraged saving and investment in his words:

When the limitation of consumption is combined with the release of acquisitive activity, the inevitable result is obvious: accumulation of capital through an ascetic compulsion to save. The restraints that were imposed on the consumption of wealth naturally served to increase it, by making possible the productive investment of capital [Weber, 1958].

This is apparent in Nigerian [protestant]) churches. Teachings in the church are centered on success in life and individuals capability to create wealth. Poverty is seen as a curse and therefore not of God. It is generally believed God owns the earth and everything in it and if anyone is truly his child, he cannot be poor. So being wealthy is a demonstration that one has possessed his rightful inheritance from God as his child. Poverty is an affliction from the devil and one has to break out of the grip of the devil and move into the realm of wealth which is the inheritance of the children of God. For one to successfully do this, spiritual [prayers] and physical [hard work] efforts are needed.

On the long run, such teachings would have positively affected the economy of the country by making people to work hard in their various places of work not just to make a living but also to fulfill their religions calling of being successful on earth. Many churches have even gone beyond just mere teachings to demonstration of how to create wealth by creating jobs through investing in different sectors of Nigerian economy such as education, transportation, agriculture, trade etc.

Hitherto, Religion has positively affected Nigerian people socially and economically through its teachings and demonstrations. People are taught to believe in their capability to create wealth, jobs have been created both directly or indirectly by religious organizations, thereby reducing unemployment level and crime rate, taxes from investments are paid to the government and this help to boost the economy of the country thus improving the living standard of the collectivity.

\subsection{Religious Terrorism: A Paradigm}

A number of scholars and pragmatic criminologists have pointed out that the disciplines of theology, religion, and philosophy have had important thing to articulate on the subject of terrorism [Stitt, 2003; Kraemer, 2004]. It is also a fact that about a quarter of all terrorist groups and about half of the most dangerous ones on earth are primarily motivated by religious concerns [Hoffman, 1993]. They believe that God has not only approved of their action, but that God demands their action. Their course is sacred, and consists of a combined sense of hope for the future and vengeance for the past. Of these two components, the backward-looking desire for vengeance may be the more important trigger for terrorism because the forward-looking component [called apocalyptic thinking or eschatology] produces wild-eyed fanatics who are more of a danger to themselves and their own people [O'Connor, 2011].

The trick to successful use of terrorism in the name of religion rests upon convincing believers or the converts that a "neglected duty" exists in the fundamental, mainstream of the religion. Religious terrorism is therefore, not about extremism, fanaticism, sects, or cults, but is instead all about a fundamentalist or militant interpretation of the basic tenets [ibid]. Most religious traditions are filled with many violent images at their core, and destruction or selfdestruction is a central part of the logic behind religionbased terrorism [Juergensmeyer, 2001]. Evil is often defined as malignant narcissism from a theological point of view, and religion easily serves as moral cover for selfcantered terrorists and psychopaths [Stitt, 2003].

Religion has always absorbed or absolved evil and guilt in what is called theodicy, or the study of how the existence of evil can be reconciled with a good and benevolent God. Most religions theodicize evil as: [1] A test of faith; [2] a product of free will; [3] part of God's plan; or [4] functional to let people learn right from wrong; and terrorists easily make use of these established theodicies or critiques [Kraemer, 2004].

The usual pattern in religious-based terrorism is for a psychopathic, spiritual leader to arise, regarded as somewhat eccentric at first [a tendency toward messianism] but as this leader develops his charisma; he tends to appear more and more mainstream and scholarly. He begins to mingle political with religious issues [a tendency toward theocracy], and little-known religious symbols or pieces of sacred text take on new significance. Quite often, these symbols are claimed to be an important part of that religion's history that has somehow been neglected. The stage is then set for blaming somebody for the betrayal of this sacred heritage. First, the politicians in one's own country are blamed, but soon a foreign influence, like secularization or modernization is blamed. Militant religions quickly move to blaming a foreign influence for at least three reasons: [1] it does not serve the religion's survival interests; [2] it makes use of a long history of competition, animosity, and war between the world's different religions; and [3] any blaming to be done must occur on the symbolic or cosmic level, which is to say that the enemy cannot have a face, but must be some impersonal, evil-like force or influence. Hence, the most specific enemy a militant religion can have is some global trend like Secularization, Modernization, or Westernization. The strength of fundamentalism is its ability to guarantee that a radical change is coming without specifying exactly what it will look like. However, once a semi-vague enemy has been identified, the 
religious movement borrows the idea of "sovereignty" from the political realm and begins to see itself as the legitimate defender of the faith and legitimate restorer of dignity to the homeland. Most importantly, such "defenders" justify terrorist action in their accountability only to God, for it is God who has chosen them for this sacred mission in history [O'Connor, 2011].

Perhaps the most interesting aspect of religion as a theory of terrorism is how a devout believer could come to mix politics and religion. This typifies the rise and activities of religious terrorism [Boko Haram] in Northern Nigeria. First, Yusuf the dead leader came into the scene using philanthropy to attract followers by identifying gaps [poverty, corruption] in Nigerian polity. He gave the poor arms and also inculcated into them his rebellious position against Westernization and Nigerian Government; and his intention to Islamize [Sharia] the North as the only way they can escape injustice and attain the level which Allah [God] wants them to be. This is strengthened by the view that they are just tools Allah uses to do his will.

Religious terrorism can be quite extreme in its tactics. Not only does it strive to avenge a long history of persecution and injustice, but it frequently carries out preemptive attacks. Leading to massive destruction of lives and bombing of government, religious and individual properties. This is because a high level of paranoia is usually maintained about the actual degree of threat that the enemy trend poses.

Religious terrorism in Nigeria posses a significant threat to national development as it is evident in Northern Nigeria where economic and social activities in some of the highly volatile States [Jos, Kaduna, Kano, Bauchi, Yobe and Borno] have almost been grounded by the stream of killings, destruction of basic means of livelihood of the people and truncating of foreign and local investments; thereby becoming a cog on the wheel of development of the States and Nigeria at large. In all fairness, it should be said that most militant religious groups only adopt terrorism as a tactic of last resort. Religious terrorists demonstrate marvelous ingenuity in means, methods, and timing, but their target is flawed, and one can only wonder how strategically effective is their "symbolic" success from "striking at the heart of the infidels." Perhaps the whole reason for it is to bolster their reputation among other religious communities. This would be supported by the fact that most terrorist acts are scheduled on dates specifically designed to desecrate a competitor's religion.

The line of convergence in both theories is the pursuit of common good and social welfare engendered through national development. While the first theory is about how religion can motivate people to work hard in order to better their living standard and the economy the other theory explained how religion could be used to lure people to take up arms and fight for a so called 'better society' where everything is done as originally set by religion.

\section{Religious Identity and National Development}

There are three forms of religions in Nigeria; they are Christianity, Islam and Traditional. Out of the three the traditional religion is the least politically active; made up of several hundreds of ethnic groups and subgroups, villages, clans and kin groups; and, involving the worship of different gods and goddesses. In parts of the Kogi, Kwara, and Nassarawa States, masquerade activities associated with traditional religion have been a major source of conflicts [Eghosa et al, 2005]. The Ogun, Osun and Sango worshippers of south west Nigeria are examples of indigenous religious practitioners. An Austrian born Osun Priestess, Susan Wenger was a well known Osun worshipper until her death in 2008. There is no known number of indigenous faiths or practitioners in Nigeria however, they are not as numerous as the other movements in the big two religions of Nigeria. However, Christian and Muslim identities have been the bastion of religious differentiations and conflict. More often than not Nigerian Muslims are more likely than Christians to demonstrate or express religious identity with or without violence depending on the level of tolerance garnered or as occasion warrants.

In Nigeria Inter-ethnic conflict has generally had a religious element. Riots against Igbo in 1953 and in the 1960s in the north were said to be fired by religious conflict. The riots against Igbo in the north in 1966 were said to have been inspired by radio reports of mistreatment of Muslims in the south. In the 1980s, serious outbreaks between Christians and Muslims occurred in Kafanchan in southern Kaduna State in a border area between the two religions. Recently, there has been an upsurge in attacks targeting Christians in northern Nigeria, culminating in the Christmas Day massacre at a Catholic church in Madalla near the Federal Capital Territory, the massacre of worshippers in a night vigil, Lokoja Kogi State and in Gombe state just to mention a few.

In the southern part of Nigeria consisting of the Yoruba, Igbo and other minorities from the Niger Delta region and parts of the middle belt region that falls into the south of Nigeria, Christianity is the predominant religion. Up until the late 1980's most of the Christian religious movements were the orthodox churches such as the Anglican, Catholic, Baptist, Presbyterian, Methodists among other church movements that date back to the pre-20th century era. These religious movements in Nigeria were introduced to Africa by missionaries from Europe particularly Ireland, England, Portugal, Italy and America. However these days the Pentecostal churches are growing in popularity gradually phasing out the 'old fashioned churches' and bringing along with them American inspired doctrines. These days most Pentecostal churches teach prosperity, earthly success and maximize the use of flamboyant, colorful methods to drive home their points. 
The 'old fashioned preaching of salvation and striving for eternal glory' through moral uprightness is often portrayed as too rigid or misguided by the new generation Christians in Nigeria. In this league of 'churches' are the Redeemed Christian Church of God [RCCG], Nigeria's largest Pentecostal Church, Christ Embassy, Winners Chapel, The Lord's Chosen Charismatic Revival Ministry, among others. Although some Pentecostal churches are more 'spiritual' than others such as Deeper Life Bible Church and Mountain of Fire and Miracle Ministries they all have a common factor which is the believe that Christianity must be holy ghost inspired. There are also the gospel churches like the Four Square Gospel Church that have their origin dating back centuries. They are less pronounced than the Pentecostal churches but differ in their practices. Overall, the Catholic Church in Nigeria is about the largest Christian movement with an overwhelming population in the south eastern part and smaller size in other parts of the country [possibly between 20 and 30 million] followed by RCCG with an estimated 10 million members. Overall Christians in Nigeria number 55 to 60 million.

Under the rubric of Christian-Muslim spectrum are several sub-cleavages that have at one time or the other been politically salient or have the potential to be, and have generated intra-group conflicts. Among Christians, there are several denominations, including: the Protestants [Anglican, Baptist, Methodist, and Lutheran], the Catholics, the Evangelical Church of West Africa, the Seventh Day Adventists, the Jehovah's Witnesses, and a host of 'homegrown', 'white garment' [Aladura and Celestial] churches.

Muslims on the other hand belong to different sects, such as the Ahmadiyya, Sanusiyya, Tijanniyya and Quadriyya, among which there have been conflicts. There are also some umbrella organizations, which aim at the propagation of Islam. One of these is the Jamaatu Nasril Islam (JNI), which was founded by the Sardauna of Sokoto in 1961. Following the Iranian Islamic revolution of the 1970s, there was a surge of radical and fundamentalist activities especially among Muslim youths. This was the context within which some fundamentalist Muslim sects, notably the Maitatsine, Izala movement, the Muslim Brothers or Shiites, and most recently the Talibans, Boko Haram, emerged to demand, amongst others: pursuit of Islam based on Sharia law; the eradication of heretical innovations; and, the establishment of an Islamic state or theocracy [Eghosa et al, 2005]. The activities of these sects are major precipitant of the religious conflicts that pervaded the political landscape of the north since 1980s till date. Most of these involve conflicts between Muslims and Christians, with clear ethnic undertones, but some especially those involving the Izala and Boko Haram, also had anti-state mobilization.

In the 1980s religious riots occurred in and around the five cities of Kano in 1980, Kaduna in 1982, Bulum-Ketu in 1982, Jimeta in 1984 and Gombe in 1985. These riots were caused by the migration of the rural poor into urban towns during the dry seasons. An offshoot of Islam called the 'Yan Tatsine' violently rebelled against the authorities and non-members. These radical Muslims were inspired by Alhaji Mohammed Marwa Maitatsine. He was a Cameroon preacher who denigrated the government, something which led to his arrest in Nigeria in 1975, yet by 1972 many people followed him across society, ranging from the elite to Koranic students called almajirai or gardawa and unemployed migrants. Maitatsine and his followers became separate from orthodox Islam, condemning the corruption of the religious and secular elites and the wealthy upper classes' consumption of Western goods during the petrol boom of 1974-81. The Boko Haram movement has been connected to the Maitatsine movement. They want to implement Sharia law across the whole of Nigeria. Radical Islam was propagated by extreme leaders who were able to rally young, educated group of individuals brainwashed to believe that the nation would not be able to protect their religious group. The leaders were able to polarize their followers through speeches and public demonstrations.

The resent emergence of the new terror group [Boko Haram] in the North of Nigeria has affected negatively the political, economic, social and environmental situation of the region and by extension Nigerian economy. The continuous killing and destruction of lives and properties in Northern Nigeria in the name of Islam has a negative effect on the economy of the Northern States and Nigeria at large. Economic activities have almost been grounded by series of terrorist attacks in Borno and Yobe States, living people stranded, jobless, homeless and as refugees in their homeland. Many businessmen, companies both local and foreign have left those 'worst hit' States depriving government millions of tax revenue that would have been collected for upward development of the society had peace allowed to reign.

\section{Religion and Nigerian Economy}

The economy of a nation can be positively and negatively affected by religion, when positively affected it leads to the development of all the structures within the system and the effect will be felt by an upward increase in the living standard of the majority of the people, this was demonstrated by Max Weber's contribution in his work the protestant ethics and the spirit of capitalism. On the other hand the negative effect of religion can be seen in the fundamentalist's attack of the state. The Boko Haram insurgence in Nigeria today is a good example. The Northern part of the country and indeed the whole of Nigeria have been totally devastated economically by the attacks of this group. Investors are scared away in zones where there is violence, unrest and insecurity to life and investments. Nigerians are restless and circumspect of their stay up north; the threat of Boko Haram is one of those terrible issues that constantly shake the confidence of people in the state called Nigeria [Ajayi, 2012].

The development of any nation is dependent on so many 
variables, for example economic variables impact are stressed by economists [Alensina and Rodrick, 1994] while; political and social factors can also be important determinants of growth [Barro, 1996]. Religion is a source not only of intolerance, human rights violations, and extremist violence, but also of non-violent conflict transformation, the defense of human rights, integrity in government, and reconciliation and stability in divided societies [Appleby, 1996].

Analyses of the implications of diversity in Nigeria and other countries suggest diversity is a necessary but not sufficient condition for conflict. In other words, the very fact that a country has different ethnic, communal, religious, and racial groups does not make division and conflicts inevitable [Eghosa et al, 2005]. In cross-country studies, economists have revisited Weber's hypothesis. Barro and McCleary [2003] assess the effect of religious participation and beliefs on a country's rate of economic progress. Using international survey data for 59 countries drawn from the World Values Survey and the International Social Sciences Program conducted between 1981 and 1999, these authors found that greater diversity of religion is associated with higher church attendance and stronger religious beliefs. For a given level of church attendance, increases in some religious beliefs - notably belief in heaven, hell and an afterlife - tends to increase economic growth ${ }^{1}$.

This is evident in the activities of churches in Nigeria where they assist some of their devoted members not only influencing their view of success and the need to acquire wealth but also help to secure job for them; thereby helping to improve their living standard and the country at large.

Other studies have focused more on particular religions in varied historical time periods. For example, very useful insights have been gained by focusing on Islam and on Judaism. For Islam, there have been detailed investigations into financial systems in the Middle East including zakat [alms for charity] and the manner in which Islamic banks have been using a financing method equivalent to the rate of interest to overcome adverse selection and information problems. The introduction of Islamic Banking by Central Bank of Nigeria is intended to improve the economic power of the borrowers. A bank that shares profit and loss with the borrower will invariably reduce the risk of doing business than the conventional banks that 'wins' in any business they enter with their clients. This will make fund available for those that have idea of a profitable business to create wealth, employment and also add value to the economy by paying taxes to the government [Okechukwu, 2012].

Religion could also foster development through encouragement of members to acquire formal education. If formal education is significant to high standard of living, then religion may explain why there are many poor people in northern Nigeria than other regions especially SouthWest and South-East Nigeria. This is because the practice

\footnotetext{
${ }^{1}$ Sushmit N. Religion and Economic Growth and Development, [2006]. http://ssrn.com/abstract=1029285
}

of Purdah in Northern Nigeria could account for the low enrolment of women in formal educational institutions.

\section{Conclusion}

For rapid and sustainable development in Nigeria the secularity of the state should be respected by the two major religions in Nigeria, adherents of the different religious groups should imbibe the culture of tolerance. Poverty eradication programs should be forcefully implemented so as to address the problem of unemployment by majority of the youths in Nigeria. Poverty has been seen as the major catalyst leading to the rapid increase in the membership of the religious extremist groups. The rise of these sects has also been linked to the increase and aiding of religious extremist by politicians for their selfish ambitions.

As it has been vividly substantiated by Max Weber [1958] Religion is a promoter of growth as they direct people towards honesty, discipline, hard work, education, thriftiness [leading to accumulation of wealth essential for investment and further growth] and abstinence from harmful activities. Religion can also encourage violence in the name of doing the will of God by some extremists; illustrated by Nigeria contemporary condition. Religion has done more evil or damage to the unity, peace and security of Nigeria and all these have inadvertently affected the promotion of social, economic and political development of the nation.

In this paper, the two sides of Religion have been explored the positive side which can lead to accelerated development through hard work, accumulation of wealth, frugality or prudence, and reinvestment of profit for more advancement. These are contained in the ethics of religion that shuns laziness and extravagant spending. Also fanaticism and extremism has led to deep seated crisis and violence between religious groups leading to fear and insecurity. There is not gainsaying the fact that a nation that lacks peace and security drives investors away. When there are no investments in the economy there will be unemployment which can lead to abject poverty.

\section{References}

[1] Ajayi, J.O. [2012]. The Boko Haram Insurgence in Nigeria and the Threat to National Security. A paper presented at the $1^{\text {st }}$ International Conference of Faculty of Social Sciences, University of Uyo, Uyo: Leadership and African Development, held on August $7^{\text {th }}-10^{\text {th }}$ at Onyema Ugochukwu Hall, University of Uyo, Uyo. Akwa-Ibom State, Nigeria.

[2] Akwalla J. [2009]. Third World and the meaning of development www.101magazine.ca/2009/05/third-worldand-the-meaning-of-development/ Accessed $28^{\text {th }}$ September 2012

[3] Alensina, A. and Rodick, D. [1994]. Distributive Politics and Economic Growth. Quarterly Journal of Economics, CLX. 
[4] Appleby, R. S. (1996). Religion as an Agent of Conflict Transformation and Peacebuilding. In C. Crocker, F. O. Hampson, \& P. Aall, The Challenges of Managing International Conflict (pp. 821-840). Washington DC: USIP Press.

[5] Barro, R.J. (1996). Determinants of Economic Growth: A Cross-Country Empirical Study. NBER Working Paper No. 5698. Issued in August 1996. National Bureau of Economic Research NBER Program(s). Available at http://www.nber.org/papers/w5698.pdf Accessed June 28, 2014.

[6] Barro, R.J. and McCleary, R. M. (2003). Religion and Economic Growth (May 2003). National Bureau of Economic Research NBER Working Paper No. w9682. Available at SSRN http://ssrn.com/abstract $=406054$. Accessed June 28, 2014.

[7] Bellah, R. N. [1970]. Beyond Belief. New York: Harper and Row, Publishers, Inc.

[8] Benveniste, E. [1973]. Indo-European Language and Society. London: Faber \& Faber.

[9] Broom, L. and Selznick, P. [1973]. Sociology: A Text with Adapted Readings Fifth Edition. New York: Harper and Row, Publishers, Inc.

[10] Bryan S. T. [2005]. Sociology of Religion and the Expressive Revolution: The Problem of Western Individualism. Journal of Classical Sociology.2005.

[11] Cohen, J. [2002]. Protestantism and Capitalism: The Mechanisms of Influence. New York: Aldine de Gruyter.

[12] Derrida, J. Faith [1998].and Knowledge: The Two Sources of Religion at the Limits of Reason Alone, pp. 1-78 in J. Derrida and G. Vattimo (eds) Religion. Cambridge: Polity.

[13] Durkheim, E. (1947). The elementary forms of religious life (J. Swain, Trans.). Glencoe, IL: Free Press. (Original work published 1915).

[14] Eghosa E. O. and Rotimi T. S. [2005]. A History of Identities, Violence, and Stability in Nigeria. Crise Working Paper No. 6, Queen Elizabeth House, University of Oxford.

[15] Ephraim F. The Protestant Ethic and the Spirit of Capitalism. Social Research, Vol.XI, 1944, pp.62-68

[16] Haralambos, M.; Holborn, M. and Heald, R. [2004]. Sociology: Themes and Perspectives sixth edition. London: Haper Collins Publishers Limited.

[17] Hoffman, B. (1998). Inside Terrorism. New York: Columbia University Press.

[18] James W. D. [2007]. A Scientific Definition of Religion. London: Macmillan.
[19] Johnston, D. and Sampson, C. [1994]. Religion: The Missing Dimension of Statecraft. New York: Oxford Univesity Press.

[20] Juergensmeyer, M. [2001]. Terror in the mind of God: The global rise of religious violence. Berkeley: University of California Press.

[21] Kirkpatrick, L.A. (2005). Attachment, Evolution, and the Psychology of Religion. New York: Guilford Publications.

[22] Kraemer, E. [2004]. A philosopher looks at terrorism. Pp. 113-131 in Nyatepe-Coo, A. \& Zeisler-Vralsted, D. (eds.) Understanding terrorism. Upper Saddle River, NJ: Prentice Hall.

[23] O'Connor, T. [2001]. Theories of Terrorism, Mega Links in Criminal Justice. Retrieved from http://www.drtomoconnor.com/3400/3400lect01a.htm.2011

[24] Okechukwu, O. A. [2012]. Religion and National Development in Nigeria. American Academic \& Scholarly Research Journal Vol. 4, No. 4, July 2012

[25] Robert J. B. and Rachel M. M. [2003]. Religion and Economic Growth across Countries. American Sociological Review, Vol. 68, No. 5. pp. 760-781.

[26] Samuelsson, K. [1957]. Religion and Economic Action: A Critique of Max Weber. New York: Harper.

[27] Seer, D. (1979). The meaning of development with postscript. In Seers, Nafziger, Cruise O'Brien \& Bernstein Pp 9-30.

[28] Sen, A.K. (1999). Development as Freedom. New York: Alfred A. K.

[29] Smyth, M. and Robinson, G. [2001]. Researching Violently Divided Societies: Ethical and Methodological Issues. Tokyo: United Nations University Press,

[30] Stitt, B. G. [2003]. The understanding of evil: A joint quest for criminology and theology. Pp. 203-218 in R. Chairs \& B. Chilton (eds.) Star Trek Visions of Law \& Justice. Dallas: Adios Press.

[31] Tylor, E.B. (1958 [1871]). Primitive Culture: Researches into the Development of Mythology, Philosophy, Religion, Language, Arts, and Custom, 2 Vols. London: John Murray.

[32] Wallerstein, I. [1974]. The Modern World System. New York: Academic Press.

[33] Weber, M. (1958). The Protestant Ethic and the Spirit of Capitalism. New York: Scribner.

[34] Wikisource, [2007]. The Protestant Ethic and the Spirit of Capitalism. Retrieved from http://en.wikipedia.org/wiki/. 